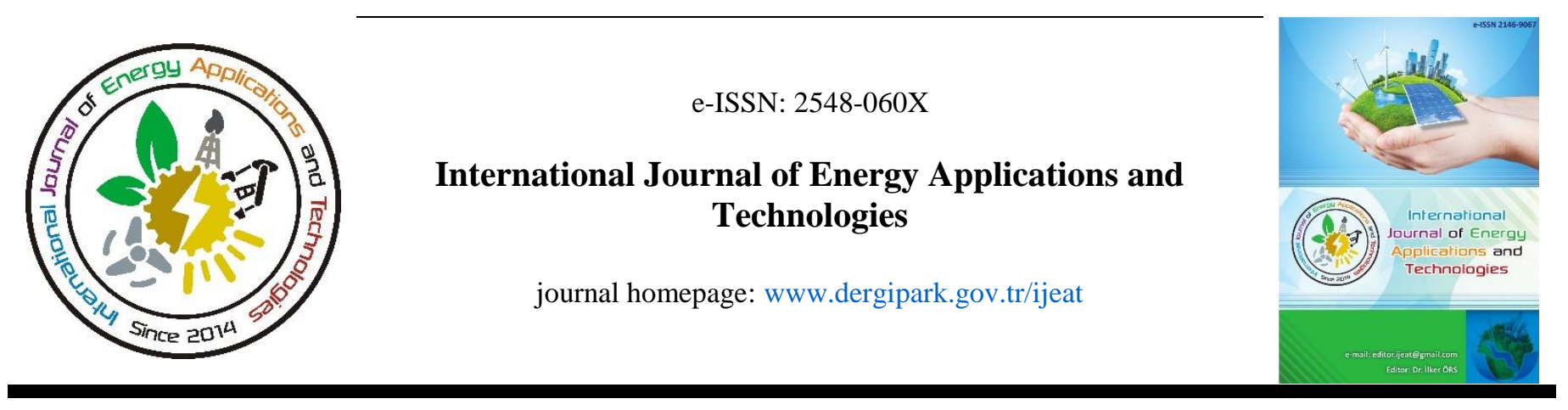

Original Research Article

\title{
Investigation of the improvement of Sivas-Kangal lignites liquefaction product yields
}

\author{
Aydan Aksoğan Korkmaz ${ }^{1 *}$,̇̀smail Bentli² \\ ${ }^{I}$ Department of Mining Technology, Hekimhan M.E.S. Vocational School, Malatya Turgut Özal University, Malatya, Turkey \\ ${ }^{2}$ Department of Mining Engineering, Faculty of Engineering, İn̈̈nü University, Malatya, Turkey
}

\author{
ARTICLE INFO \\ * Corresponding author \\ aydan.aksogan@ozal.edu.tr \\ Received May 12, 2021 \\ Accepted September 7, 2021 \\ Published by Editorial Board \\ Members of IJEAT \\ (C) This article is distributed by \\ Turk Journal Park System under \\ the CC 4.0 terms and conditions. \\ doi: $10.31593 /$ ijeat. 936840
}

\begin{abstract}
In recent years, converting and using coal into the most suitable product according to its properties has emerged as a modern approach. Among the main processes applied to coal are low and high-temperature carbonization, gasification and liquefaction. In coal liquefaction, coal is broken down into free radicals using hydrogen donor solvent and catalyst under high temperature and pressure conditions. Later, these radicals can be used in the production of both liquid fuel and chemical raw materials by being saturated with hydrogen. This study aims to improve the yields of Sivas-Kangal lignite liquefaction products (char, preasphaltene, asphaltene, oil-gas). For this purpose, firstly raw coal, then spiral enriched clean coal liquefaction experiments were carried out. The chemical characterizations of the obtained products were determined by proximate and ultimate analysis. The composition of the oil was identified by GC-MS. As a result of the enrichment, the char yield decreased by $16.5 \%$ whereas the oil+gas yield increased by $14.64 \%$. Total conversion increased from $31.74 \%$ to $48.24 \%$. It has been concluded that the enrichment process has a positive effect on the liquefaction yields.
\end{abstract}

Keywords: Asphaltane; Lignite; Liquefaction; Oil; Preasphaltane

\section{Introduction}

Because of the organic and inorganic compounds contained in coal, it is important not only to meet the energy need but also to be a source of chemical raw materials. For this reason, various processes such as pyrolysis and liquefaction have been tried to produce solid and liquid fuels or chemical raw materials from coal. There are many studies on this subject in the literature [1-6].

The structure of coal is different from that of the hydrocarbons in petroleum. The principal difference between coal and petroleum is due to the lower $\mathrm{H} / \mathrm{C}$ ratio of coal. The $\mathrm{H} / \mathrm{C}$ ratio is not just the molar $\mathrm{H} / \mathrm{C}$ ratio, but the molar ratio of $\mathrm{H} / \mathrm{C}$ after subtracting the $\mathrm{H}$ needed to eliminate $\mathrm{N}, \mathrm{S}$ and $\mathrm{O}$ from the product [7]. Therefore, to convert coal into liquid products it is necessary to increase the $\mathrm{H} / \mathrm{C}$ ratio in the products compared with the original coal. This is accomplished by direct hydrogenation or by the removal of carbon. Indirect liquefaction processes involve the gasification of coal in a fixed or fluidized bed reactor followed by the conversion of the synthesis gas into liquid hydrocarbons. Catalytic liquefaction processes are carried out in the presence of active catalysts to produce hydrocarbons directly, and the rehydrogenation of solvents occurs in situ. When catalysts are not used, the process is usually known as solvent extraction. Solvent extraction has been used for many years as a useful method to investigate coal structure. In catalytic and non-catalytic processes, coal is slurried in a coal-derived solvent and heated to $400-500^{\circ} \mathrm{C}$ for varying lengths of time. Since, in non-catalytic processes, coal minerals may also play the role of catalyst, and both processes are essentially hydroliquefaction processes, the distinction between the two processes is actually not justified [8]. 
The material extracted from coal may be separated into various fractions according to its solubility in a particular solvent (such as hexane, toluene, THF). It was decided to use the classification of oils (soluble in hexane), asphaltenes (soluble in toluene) and preasphaltenes (insoluble in toluene) for this study [9, 10].

In the present study, Kangal lignite liquefaction studies were carried out in non-catalytic conditions in a nitrogen gas atmosphere. The effect of the enrichment process of the liquefaction products was investigated by comparing the product yields.

The material extracted by coal/solvent contacting was Soxhlet extracted successively by tetrahydrofuran (THF, $\left.\mathrm{C}_{4} \mathrm{H}_{8} \mathrm{O}\right)$, hexane $\left(\mathrm{C}_{6} \mathrm{H}_{14}\right)$, and toluene $\left(\mathrm{C}_{7} \mathrm{H}_{8}\right)$ to yield oil, asphaltene, and preasphaltene respectively.

In the literature, there are some investigations related to the liquefaction product yields of the lignite [11-13]. However, the effect of the enrichment in the liquefaction process on the properties of the obtained products has not been fully studied yet.

\section{Materials and Methods}

The lignite sample used in this research was acquired from Kangal-Sivas, which is located in the Internal Anatolia of Turkey. The lignite samples were prepared according to the ASTM standards (ASTM D3173, ASTM D3174 and ASTM D3175) for gross calorific value, proximate and elemental analysis.

The spiral tests were performed using a Reichert spiral with 5-launders. The tests were done at different size fractions ($3.35+2,-2+1.18$ and $-1.18+0.15 \mathrm{~mm}$ ), different solid/liquid ratio $(7.5,15,25$ and $35 \%$ solid by wt.) and different splitter settings $\left(90,120\right.$ and $\left.150^{\circ}\right)$. The cleanest coal obtained as a result of these experiments was used for liquefaction. The results of the proximate and elemental analysis of raw and clean coal of Kangal lignite are given in Table 1.

Table 1. Proximate and elemental analysis results of raw and clean coal of Kangal lignite (on air-dried basis)

\begin{tabular}{lcc}
\hline Component & Raw coal & Clean coal \\
\hline Moisture (\%) & 5.83 & 4.98 \\
Ash (\%) & 43.66 & 20.41 \\
Volatile matter (\%) & 31.91 & 12.34 \\
Fixed C (by difference) (\%) & 18.60 & 62.27 \\
Total S (\%) & 2.94 & 1.29 \\
\hline \multicolumn{3}{c}{ Elemental analysis } \\
\hline C (\%) & 22.81 & 35.41 \\
H (\%) & 1.40 & 2.84 \\
N (\%) & 0.36 & 0.45 \\
S (\%) & 2.95 & 1,97 \\
O (by difference) (\%) & 72.48 & 59.33 \\
H/C molar ratio & 0.74 & 0.96 \\
Higher heating value (kcal/kg) & 2860 & 3990 \\
\hline
\end{tabular}

The samples were ground and the -106 micron size fraction was employed for liquefaction. Tetrahydrofuran (Merck, 99.0\%), tetralin (Merck, 98\%), n-hexane (Riedel-de Haen, 95\%), toluene (Riedel-de Haen, 99.7\%), ethylene glycol (EG), acetone, and ethanol were used in the study. Liquefaction experiments were done using a mechanically stirred and electrically heated closed system $500 \mathrm{~cm}^{3}$ stainless-steel Parr reactor (PARR-USA Brand Model 4575). For each experiment, $30 \mathrm{~g}$ of the coal was put into the Parr autoclave and $90 \mathrm{~cm}^{3}$ of tetralin $\left(\mathrm{C}_{10} \mathrm{H}_{12}\right)$ without any catalyst was added on it, and the autoclave was sealed and the pressure was adjusted to 20 bar by $\mathrm{N}_{2}$. The autoclave was heated at about $3-4{ }^{\circ} \mathrm{C} / \mathrm{min}$ and waited for 2 hours at $400{ }^{\circ} \mathrm{C}$. It was mixed at a constant speed of $400 \mathrm{rpm}$ during both heating and reaction. The autoclave was heated until $400^{\circ} \mathrm{C}$ at $60 \mathrm{~min}$ and then cooled to room temperature into an icewater bath. The char, asphaltene, preasphaltene, and oil were separated from each other using the Soxhlet solvent extraction and evaporator system. The flow chart for the classification of coal liquefaction products is given in Figure 1. Total conversions of liquefaction products were calculated according to the results of solvent extraction and char yields. The effect of the enrichment on the properties of the liquefaction products and oil yield was determined using mass balance equations.

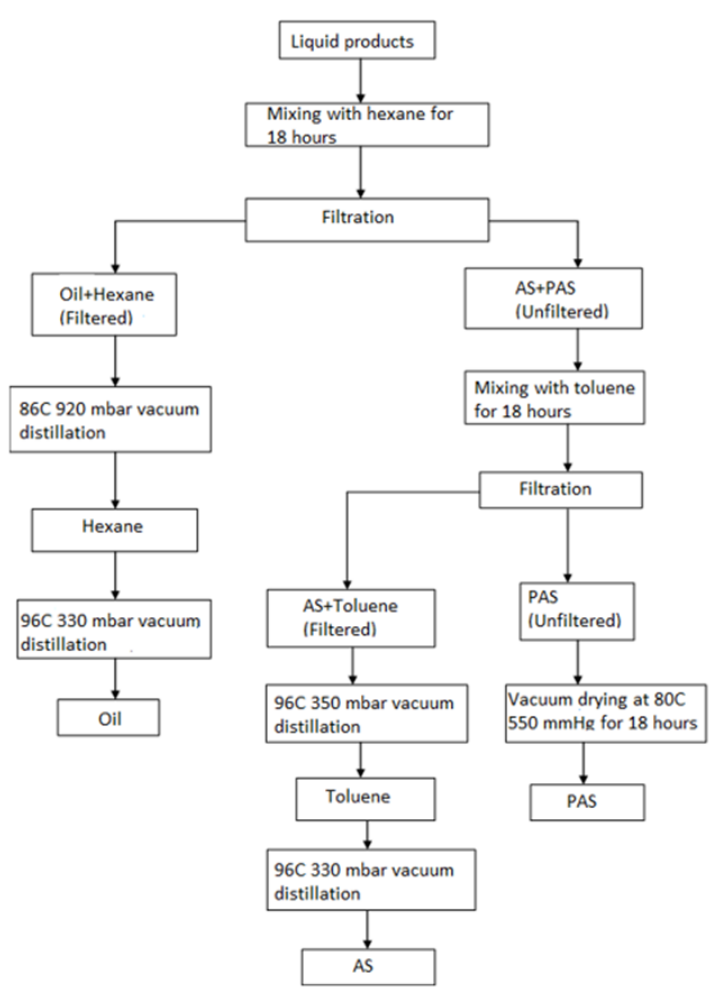

Fig. 1. Flow chart of coal liquefaction

Characterization and chemical structure of the liquefaction products were subjected using CHNS Elemental analyzer device (Leco CHNS 932, LECO Corporation, St. Joseph, 
MI), IKA C-1 calorimeter, Agilent Technologies $6890 \mathrm{~N}$ Network GC System model gas chromatography, and Agilent Technologies 5973 inert Mass Selective Detector mass spectrometer (Agilent Technologies, Santa Clara, CA) at the laboratory of Inonu University Scientific and Technology Center Research.

\section{Result and Discussion}

The proximate analysis results of the char of raw and clean coal are given in Table 2 .

The elemental analysis results of the liquefaction products (char, preasphaltane and oil) of raw and clean coal are given in Table 3. Elemental analysis and calorific values of asphaltene products cannot be determined due to the difficulty of removing them from glass systems and the amount of material is small.

Table 3 shows that the $\mathrm{C}$ content and calorific value of all products in clean coal are increased. Therefore, it can be said that the enrichment process has a positive effect on liquefaction products.
Table 2. The proximate analysis results of the char of raw and clean coal

\begin{tabular}{lcc}
\hline Char & Raw coal & Clean coal \\
Ash $(\%)$ & 25.08 & 20.41 \\
Volatile matter $(\%)$ & 18.03 & 15.06 \\
Fixed C* $(\%)$ & 10.68 & 29.37 \\
*by difference & &
\end{tabular}

In Table 4, the yield and total conversions of the products obtained as a result of liquefaction of raw and clean coal are given.

According to Table 4, while asphaltane and oil+gas yields increased in clean coal, the preasphaltane yield was unchanged. The total conversion of clean coal has increased. GC-MS chromatogram of oils is given in Figure 2 and Figure 3 , and chemical compounds in Table 5.

As seen in Table 5, the main compounds of the oil were determined as saturated n-alkenes, isoprenoids, branched alkenes, n-alkyl cyclohexane, terpene and other aromatic structures, like the literature data [10, 14-17]. Also, the enrichment process was found to not affect the oil composition.

Table 3. Elemental analysis results of the liquefaction products of raw and clean coal

\begin{tabular}{|c|c|c|c|c|c|c|}
\hline & Raw coal char & Clean coal char & Raw coal preasphaltane & Clean coal preasphaltane & Raw coal oil & Clean coal oil \\
\hline \multicolumn{7}{|c|}{ Elemental analysis (\%) } \\
\hline $\mathbf{C}$ & 51.10 & 64.72 & 72.16 & 79.21 & 73.46 & 85.14 \\
\hline $\mathbf{H}$ & 3.65 & 5.36 & 5.59 & 6.56 & 7.02 & 8.96 \\
\hline $\mathbf{N}$ & 1.70 & 1.18 & 1.19 & 1.34 & 0.41 & 0.30 \\
\hline $\mathbf{S}$ & 2.54 & 1.82 & 0.92 & 0.71 & 0.39 & 0.26 \\
\hline O* & 41.01 & 26.92 & 20.14 & 12.18 & 18.72 & 5.34 \\
\hline $\mathrm{H} / \mathrm{C}$ & 0.86 & 0.99 & 0.93 & 0.99 & 1.15 & 1.26 \\
\hline \multicolumn{7}{|c|}{ Higher heating value (kcal/kg) } \\
\hline & 6903 & 7083 & 7817 & 7961 & 4374 & 4991 \\
\hline
\end{tabular}

Table 4. The yield and total conversions of the products obtained as a result of liquefaction of raw and clean coal

\begin{tabular}{cccccc}
\hline Yield (\%) & Char & Preasphaltane & Asphaltane & Oil+Gas & Total conversion \\
\hline Raw coal & 68.26 & 10.62 & 3.33 & 17.79 & 31.74 \\
Clean coal & 51.76 & 10.80 & 5.00 & 32.44 & 48.24 \\
\hline
\end{tabular}

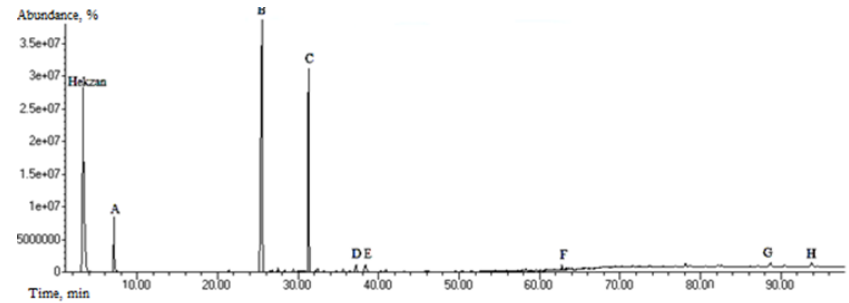

Fig. 2. GC-MS chromatogram of the obtained oil as a result of liquefaction of raw coal

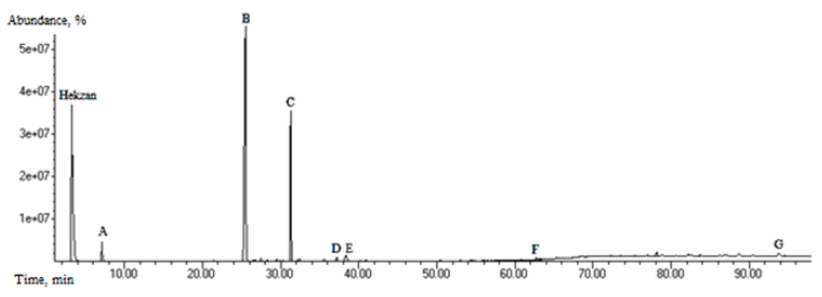

Fig. 3. GC-MS chromatogram of the obtained oil as a result of liquefaction of clean coal 
Table 5. GC-MS analysis of the oil obtained from liquefaction of raw and clean coal and the detected compounds in the oil structure

\begin{tabular}{|c|c|c|c|c|c|c|}
\hline \multirow[t]{2}{*}{ Peak No } & \multicolumn{2}{|c|}{ Retention time (min) } & \multicolumn{2}{|c|}{ Probable Compound } & \multicolumn{2}{|c|}{ Abundance (\%) } \\
\hline & Raw coal & Clean coal & Raw coal & Clean coal & Raw coal & Clean coal \\
\hline A & 7.101 & 7.129 & Toluene & Toluene & 6.38 & 2.50 \\
\hline $\mathrm{B}$ & 25.485 & 25.497 & $\begin{array}{l}\text { Naphthalene, 1,2,3,4- } \\
\text { tetrahydro, Tetraline }\end{array}$ & Naphthalene, 1,2,3,4- tetrahydro, Tetraline & 53.54 & 59.55 \\
\hline $\mathrm{C}$ & 31.293 & 31.287 & $\begin{array}{c}\text { Azulene } \\
\text { Naphthalene } \\
\end{array}$ & $\begin{array}{c}\text { Azulene } \\
\text { Naphthalene } \\
\end{array}$ & 30.42 & 25.61 \\
\hline $\mathrm{D}$ & 32.634 & 32.631 & $\begin{array}{l}\text { Naphthalene, } 1,2,3,4- \\
\text { tetrahydro-1-propyl }\end{array}$ & Naphthalene, 1,2,3,4-tetrahydro-1-propyl & 0.84 & 0.86 \\
\hline $\mathrm{E}$ & 37.215 & 37.232 & $\begin{array}{l}\text { Naphthalene, 2-methyl } \\
\text { Naphthalene, 1-methyl }\end{array}$ & $\begin{array}{l}\text { Naphthalene, 2-methyl } \\
\text { Naphthalene, 1-methyl }\end{array}$ & 1.28 & 0.73 \\
\hline $\mathrm{F}$ & 62.775 & 62.781 & Benzen,1,3-diethyl-5-methyl & Benzen,1,3-diethyl-5-methyl & 0.68 & 0.40 \\
\hline $\mathrm{G}$ & 88.673 & 93.783 & $\begin{array}{l}\text { 2,2'-binaphthalene, 1,1', } \\
\text { 2,2', 3,3', 4,4'- octahydro- }\end{array}$ & $\begin{array}{c}\text { 1,2,3,10,11,12-hekzahydro perlin } \\
7,8,9,10,11,12 \text {-hekzahydro benzo [a]piren }\end{array}$ & 1.37 & 1.03 \\
\hline $\mathrm{H}$ & 93.794 & & $\begin{array}{l}7,8,9,10,11,12 \text {-hekza hydro } \\
\text { benzo [a]piren }\end{array}$ & & 1.28 & \\
\hline
\end{tabular}

\section{Conclusion}

In the liquefaction studies with raw coal, char yield was $68.26 \%$, preasfaltene yield was $10.62 \%$, asphaltene yield was $3.33 \%$ and oil + gas yield was $17.79 \%$. As a result of the liquefaction of the clean coal, the char yield decreased by $16.5 \%$, the asphaltene yield increased by $1.67 \%$ and the oil + gas yield increased by $14.64 \%$, while the preasphaltene yield remained unchanged. Total conversion increased from $31.74 \%$ to $48.24 \%$ (Table 3 ).

The calorific value of all products in clean coal is increased (for char from $6903 \mathrm{kcal} / \mathrm{kg}$ to $7083 \mathrm{kcal} / \mathrm{kg}$, for preasphaltene from $7817 \mathrm{kcal} / \mathrm{kg}$ to $7961 \mathrm{kcal} / \mathrm{kg}$, for oil from $4374 \mathrm{kcal} / \mathrm{kg}$ to $4991 \mathrm{kcal} / \mathrm{kg}$ ).

According to GC-MS results, the main compounds of the oil were determined as naphthalene and its derivatives, tetraline, azulene, binaphthalene and benzene. In the oil of clean coal, no compounds were found that did not exist in raw coal. As seen in Table 4, the clean coal oil yield for the liquefaction process was founded as $32.44 \%$ to be higher than the raw coal oil yield (17.79\%). From these results, it has been found that the enrichment process has a very positive effect on the liquefaction products, especially on the oil + gas yield.

Finally, it was suggested that the production of a more valuable product using the lignite having low calorific value will not only contribute more to the country's economy but also be better for the environment. However, it is necessary to investigate the economics of the theoretically and practically possible liquefaction method.

\section{Acknowledgment}

I would like to express my gratitude to my supervisor Assoc. Prof. Ismail Bentli for all his guidance and helpful advice throughout this study. The research presented in this publication was funded by the Inonu University Scientific Research Projects (BAP) unit (Project No. 2015/34).

\section{ORCID}

A. A. Korkmaz

0000-0002-3309-9719

İ. Bentli 0000-0003-3775-7341

\section{References}

[1] Lievens, C., Ci, D., Bai, Y., Ma, L., Zhang, R., Chen, J.Y., and Gai, Q. 2013. A study of slow pyrolysis of one low rank coal via pyrolysis-GC/MS. Fuel Processing Technology, 116, 85-93.

[2] Xu, Y., Zhang, Y., Wang, Y., Zhang, G., and Chen, L. 2013. Gas evolution characteristics of lignite during low-temperature pyrolysis. Journal of Analytical and Applied Pyrolysis, 104, 625-631.

[3] Meng, F., Yu, J., Tahmasebi, A., Han, Y., Zhao, H., Lucas, J., and Wall, T. 2013. Characteristics of chars from low-temperature pyrolysis of lignite. Energy Fuels, 28, 275-284.

[4] He, Q., Wan, K., Hoadley, A., Yeasmin, H., and Miao, Z. 2015. TG-GC-MS study of volatile products from Shengli lignite pyrolysis. Fuel, 156, 121-128.

[5] Li, X., Xue, Y., Feng, J., Yi, Q., Li, W., Guo, X., and Liu, K. 2015. Co-pyrolysis of lignite and Shendong coal direct liquefaction residue. Fuel, 144, 342-348.

[6] Kanca, A., Dodd, M., Reimer, J.A., and Uner, D. 2016. Following the structure and reactivity of Tunçbilek lignite during pyrolysis and hydrogenation. Fuel Processing Technology, 152, 266-273.

[7] Rahman, M., Adesanwo, T., Gupta, R., and Klerk, A. 2015. Effect of direct coal liquefaction conditions on coal liquid quality. Energy and Fuels, 29, 3649-3657.

[8] Kural, O. Coal Resources, Properties, Utilization, Pollution, Istanbul: Ozgun Press, Turkey, 1994, 85-96.

[9] Ekinci, E., Yardim, F., Razvigorova, M., Minkova, V., Goranova, M., Petrov, N. and Budinova, T. 2002. Characterization of liquid products from pyrolysis of subbituminous coals. Fuel Processing Technology, 7778, 309-315. 
[10] Karaca, H., and Koyunuoğlu, C. 2010b. The coliquefaction of Elbistan lignite and biomass Part II: The characterization of liquefaction products. Energy Sources, Part A: Recovery, Utilization and Environmental Effects, 32, 1167-1175.

[11] Gözmen, B., Artok, L., Erbatur, G., and Erbatur, O. 2002. Direct liquefaction of high-sufur coals: effects of the catalyst, the solvent and the mineral matter. Energy and Fuels, 16, 1040-1047.

[12] Hesenov, A., Gül, Ö., Gafarova, P., Erbatur, O., and Schobert, H.H. 2004. Distribution of main product fractions in co-liquefaction of high-sulfur lignites blended with petroleum heavy bottoms. Prepr.Pap.Am.Chem.Soc., Div.Fuel Chem., 49, 500-502.

[13] Gül, Ö., Gafarova, P., Hesenov, A., Schobert, H.H., and Erbatur, O. 2004. Catalytic direct liquefaction of high sülfür lignites: temperature and solvent effect on product distributions. Prepr.Pap.-Am.Chem.Soc., Div.Fuel Chem., 49, 559-561.

[14] Speight, J.G. The Chemistry and Technology of Coal (2nd Edition), New York: Marcel Dekker Inc., USA, 1994, 156-178.

[15] Methakhup, S., Ngamprasertsith, S., and Prasassarakich, P. 2007. Improvement of oil yield and its distribution from coal extraction using sulfide catalysts. Fuel, 86, 2485-2490.

[16] Karaca, H., and Koyunuoğlu, C. 2010a. Co-liquefaction of Elbistan lignite and biomass Part I: The effect of the process parameters on the conversion of liquefaction products. Energy Sources, Part A: Recovery, Utilization and Environmental Effects, 32, 495-511.

[17] Wang, Z., Shui, H., Pan, C., Li, L., Ren, S., Lei, Z., Kang, S., Wei, C., and Hu, J. 2014. Structural characterization of the thermal extracts of lignite. Fuel Processing Technology, 120, 8-15. 